LIUDMILA FAKEYEVA

Belarusian State University, Minsk, Belarus

Aliaksei SHADRAKov

Regional Centre of the Mogilev Region of the Economy Research Institute of the Ministry of Economy of the Republic of Belarus, Mogilev, Belarus

\title{
Demographic and Labor Potential as the Factors of Agroecotourism Development in Belarus (on the Example of Brest and Grodno Regions)
}

\begin{abstract}
In the following article demographic development is analysed as a factor of agroecotourism development in Belarus with special emphasis on Brest and Grodno Regions as areas with the highest potential for rural tourism progress and expansion. The potential role for rural tourism development of demographic potential, labor resources and settlement system is revealed. The demographic development of Belarusian rural areas is presented for the period of 1970-2013. The article aims to work out the typology of districts in accordance with peculiarities of demographic development during this period. The article also aims to trace the main factors of demographic spatial inequality in rural areas in Belarus.
\end{abstract}

Keywords: agroecotourism; Belarus; Brest Region; demographic potential; Grodno region

Received: 24 January 2016

Accepted: 19 July 2016

Suggested citation:

Fakeyeva, L., Shadrakov, A. (2016). Demographic and Labor Potential as the Factors of Agroecotourism Development in Belarus (on the Example of Brest and Grodno Regions). Prace Komisji Geografii Przemysłu Polskiego Towarzystwa Geograficznego [Studies of the Industrial Geography Commission of the Polish Geographical Society], 30(4), 133-143.

\section{INTRODUCTION}

The impact of demographic factors on the development of agroecotourism is manifested in two directions: on the one hand, it determines the potential demand for tourist service, on the other hand - labor resources potential of the branch. These factors may have a positive or negative effect on the development of tourism in general and agroecotourism in particular.

The aim of the article is to evaluate the impact of demographic factors on the development of rural tourism in Belarus on the example of Brest and Grodno Regions as areas with the highest potential for rural tourism progress and expansion.

The demand for all kinds of tourist services is formed on the basis of generating and realizing factors of spatial-recreational systems by V.S. Preobrazhensky, V.I. Azar, I.V. Zorin (Gaidukevich, L.M., 2001) taking into account sector specific issues. 
The demand for the agroecotourism service is generally formed in big cities. Due to this the assessment of the level of urbanization can be one of the main quantitative criteria of analyzing potential demand. The specific nature of the process of urbanization in Belarus and relatively recent completion of the urbanization transition (in 1975 the share of the urban population reached 50\%) define links of a large part of rural residents. As a consequence, it reduces the rural tourism demand potential even in large cities.

From the point of view of the evaluation of generating factors of agroecotourism development, the role of urbanization was regarded as neutral, as the main centers of demand may be outside of the studied region, and the defining parameters become the following: geographical availability of farmsteads, their authentication, the quality of provided services, capacity, etc. (Tupitsyna, N.B., 2015).

In our opinion, the most important factors related to the demographic component which can both directly and indirectly influence the development of agroecotourism in Belarus are the factor of demographic potential, the labor resource factor and the settlement factor.

\section{The Demographic Potential Factor}

In Belarus the demographic potential of rural areas has been reducing for almost fifty years. The basis for this is migration from rural to urban areas under heavy industrialization in the 1970s-1980s; evolutionary changes in the nature of natural population movements which appeared to reduce the birth rate; and the aging of the population.

In the 1960s there has been a steady upward trend in mortality and declining fertility in the rural area in Belarus. In the middle of the 1970s the rural population of certain areas began to decline due to natural movement, and in 1980 natural population decline was first noted for the whole rural area of Belarus. These negative trends were just increasing in the following years, and as a result the current demographic situation is characterized by a reduction of the total population, age structure damage, and the overall aging of the population.

Herewith these processes have significant territorial differences in the context of regions (Fig. 1). The rural areas of the Western Belarus are distinguished by more positive trends of demographic development. First of all, it concerns the Brest region where the rural area is the most demographically stable in the country.

The sustainability of demographic development of rural areas in Brest and Grodno regions is largely determined by the level of agriculture development, which in turn acts as a consequence of historical, agro resource and population distribution factors.

The main means of production in agriculture is the land. Its quality characteristics determine the potential for economic development of agricultural enterprise and, as a result, the population's standard of living.

This spatial inequality of agricultural development is due to the fact that an agricultural sector that was rather productive and high-tech by Soviet standards was created in the western region of Belarus during the post-war years. According to Kliunya V.L. (Kliunya, 2000), the formation and development particularity of the Belarusian 
Fig. 1. The character of the dynamic of the demographic development components of the regions of Belarus, 1970-2013

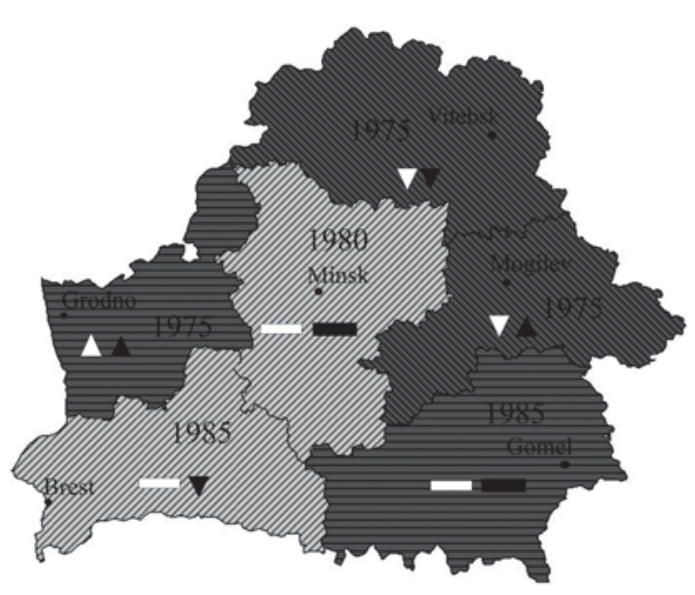

Source: developed by authors based on NSC data

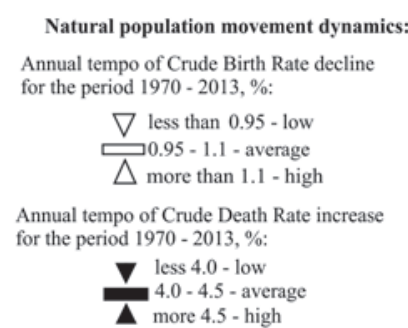

1975

the year when depopulation start

Rural population size decline for the period $1940-2013$ years, $\%$ :

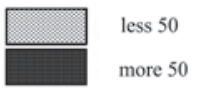

Average annual tempo of rural population size decline for the period $1970-2013$ years, \%

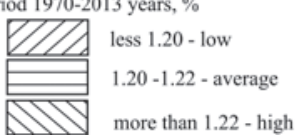

agro-industrial complex is due to the fact that a large part of industrial production is concentrated in the part of the country, which until 1939 was part of the USSR, so the western part of the country was largely agrarian, and "the relative success of agriculture in Western Belarus to a certain extent is determined by the hidden and overt subsidies at the expense of the industrial East" (Kliunya, 2000: 10).

Brest and Grodno regions were characterized by higher final production figures (agricultural production, the gross income per 1 ha of agricultural land), as well as by political reasons, the availability of favorable natural conditions and high labor potential (Leschilovskiy, 1998). Even now with a high total score of cadastral valuation the value of the gross income from 1 ha of agricultural land is greater than the average in the country.

While evaluating the factors determining Belarusian rural areas demographic development, at the micro-geographic level of peculiar districts, the authors traced the territorial differences of the role of agro-economic factors for the western and eastern regions of the country. Thus, in 1970, two agro-intensive areas with the greatest economic development - Central (Kletsk, Kopyl, Nesvizh, Korelichy districts) and Eastern (Shklov, Tolochin, Gorki, Mstislavl districts) (Pirozhnik, 1986) were allocated. The districts situated along the "forest meridian" on the line Rossony - Lelchytsy are characterized by the lowest reclamation. The economic potential of these districts is below the average for rural areas, but the natural environment is better preserved in these territories (Gartsueva, 2007: 223).

By 1989 no significant spatial transformation of the existing areas has taken place, and in the early 2000s there has been a visible increase in the influence of the level of 
economic development on the natural movement of rural population to the west. The East area has narrowed, the Central area has strengthened and complemented Minsk industrial urbanized district, the Western area is clearly formed, which is represented by agro-intensive and industrial-agricultural districts of Grodno and Brest regions (Voronovo, Schuchin, Berestovitsa, Volkovysk, Zelva, Bereza, Ivanovo, Zhabinka districts) (Fakeyeva, 2009).

Thus, currently the highest level of economic development and agricultural production are characteristic of the districts of Grodno and Brest regions, as well as Nesvizh, Kopyl, Slutsk and Minsk districts in Minsk region, and Gorki, Dribin and Shklov districts in Mogilev region. High agro resource potential, its rational use and intensive agriculture in most districts of Brest and Grodno regions provide the basis for maintaining the demographic potential and settlement system - it holds the migration outflow of population from rural areas, which in turn has a positive effect on the age structure, the availability of human resources and demographic dynamics (Fakeyeva, 2009). The typology analysis of Belarusian regions according to the nature of the dynamics of rural population indicates that the rural areas most stable in demographic development are mostly located in the Brest region (Fig. 2).

The typology was based on the dynamics of the share of district population in the general rural Bealrusian population. On the basis of qualitative characteristics of the dynamics of districts shares (stability, growth or decline) the focus of spatial shifts of the center of influence of demographic potential for the period 1970-2013 has been identified.

As a result three types of population dynamics have been distinguished. They are: stable, growing and declining. Districts of the declining dynamics type have reduced

Fig. 2. Regional types of population dynamics of the rural Belarusian population for the period 1970-2013

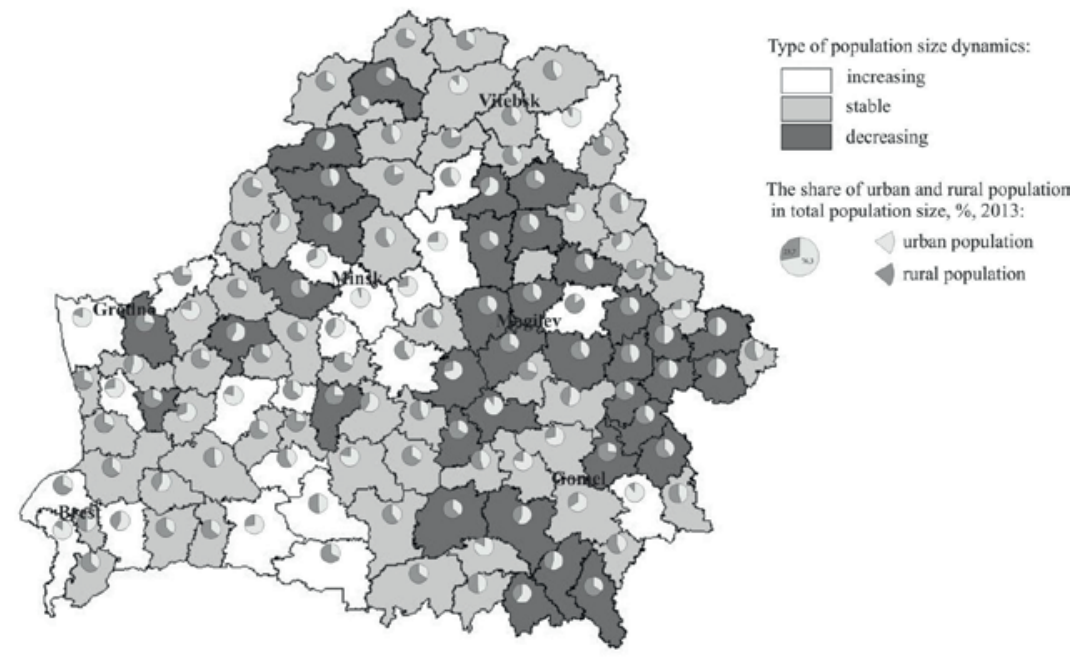

Source: developed by authors based on NSC data 
the share in total rural population over $0.1 \%$ for the studied period; the districts of a growing type have increased the share of the population over $0.1 \%$. The districts with fluctuations of the population share within these rates are singled out into a stable type of dynamics (Tab. 1).

Tab. 1. Characteristics of the dynamics types of the rural population

\begin{tabular}{|c|c|c|c|c|c|c|}
\hline \multirow{2}{*}{$\begin{array}{l}\text { Type of } \\
\text { districts }\end{array}$} & \multirow{2}{*}{$\begin{array}{l}\text { Number of } \\
\text { districts }\end{array}$} & \multicolumn{2}{|c|}{$\begin{array}{c}\text { Share of population } \\
(\%)\end{array}$} & \multicolumn{2}{|c|}{$\begin{array}{c}\text { Share of territory } \\
(\%)\end{array}$} & \multirow{2}{*}{$\begin{array}{c}\text { Urbanization } \\
(\%)\end{array}$} \\
\hline & & 1970 & 2013 & 1970 & 2013 & \\
\hline Type 1 & 22 & 18,9 & 19,2 & 20,0 & 47,1 & 71,8 \\
\hline Type 2 & 60 & 49,6 & 50,6 & 48,7 & 48,0 & 74,8 \\
\hline Type 3 & 36 & 31,5 & 30,2 & 31,3 & 33,2 & 63,7 \\
\hline
\end{tabular}

Source: developed by authors based on NSC data

Type 1 includes two district subtypes - the Southern agrarian districts of Polesye and big city suburban areas and transport corridors.

Southern agricultural regions of Polesye (Stolin, Gantsevichi, Luninets) which traditionally have a more favorable demographic situation are characterized by the increasing proportion of the population. These are typically agricultural areas with high agro resource potential, and they are characterized by the increase in the proportion of population throughout the studied period.

These typically rural areas, which have preserved not only the demographic potential, but a rural way of life, are the most promising in terms of the development of agroecotourism.

The most populated group of growing districts does not have a uniform natural area. This is a dispersive district suburban zone subtype of big cities and transport corridors, the population share of which is constantly increasing. Despite its demographic stability, this district subtype does not have such powerful potential for the development of agroecotourism as southern agricultural districts due to the fact that rural areas in these districts are themselves a transition area from urban to rural territory with low employment in agriculture.

\section{The LABOR RESOURCE FACTOR}

In the second half of the 20th century and in the beginning of the 21 st century the dynamic of age structure of rural population is regressive, resulting in the increase in the share of older and aging population, reducing the proportion of children and labor potential depleted in rural areas as a result. The population of all age groups is reduced, but the highest rate of reduction is of the people of pre-labor age, and the lowest one is of post-labor age, which leads to the transition from a progressive type of age structure to a regressive one.

Undoubtedly, the transformations in the population age structure create a problem of labor resource availability in the rural area. However, when considering it in regard to agroecotourism, this factor may be included into the group of contributing not 
holding ones, only not by itself but in combination with other factors such as economic, cultural, historical, natural and environmental.

Certainly, if there are people of a working age in the rural area, it plays a core role in the possibility of agroecofarmsteads' functioning. The population aging as a positive development factor can be considered in the context of the impact of cultural and historical factors. In this section we do not talk about all the aspects of cultural and historical factors' impact on the development of agroecotourism, we will consider only the demographic component. The impact of cultural and historical factors is mostly manifested in a careful preservation of non-material culture (ancient ceremonies, songs, recipes of traditional cuisine etc.). The aging of population and a regressive age structure, which is generally regarded as a negative component in demographic research, in this case, on the contrary, may have beneficial effects. Here elderly people may be regarded as the guardians of traditions. And their restoration and use in the work of farmsteads may provide or increase the authenticity of agroecotourism objects.

The share of population of post-working age both in Grodno and Brest regions is increasing, and according to the data of 2013 it amounted to $23.4 \%$ and $23.9 \%$ correspondingly, and $35.6 \%$ and $31,0 \%$ in rural areas.

Back in the early 1970s in general the population of Belarus of pre-labor age exceeded the number of post-labor age by a third, and by 1979 these age groups became equal in number. Nowadays the age structure of all regions in Belarus is of a regressive type, but the value of the regression index of the age structure varies from 1.1 in the Brest region to 3.4 in Novogrudok.

At present, almost all areas of Belarus with the share of people older than working age over 30\% are located in Grodno region: Dyatlovo (30.1\%), Zelva (33.2\%), Korelichi (34.6\%), Novogrudok (31.7\%), Svisloch (31.5\%) and Schuchin (31.8\%) districts, and one district with such a high proportion of elderly people is in Brest region, the Gantsevichi district (32.8\%).

The analysis of spatial and temporal characteristics of the population age structure dynamics indicates that in rural areas of Belarus a concentration of districts with an extremely high share of elderly people in Grodno region, where the number was 6 out of 17 has taken place by now. Herewith the aging process is not as intense in Brest region and does not differ significantly from the national average.

\section{The Settlement System Factor}

In the second half of the 20th century there was a significant transformation of the rural settlement system in Belarus: out of a predominantly agrarian country it became an industrial country with the dominant urban settlement system (Pirozhnik, 2000: 78).

In 1960s and 1970s the formation and consolidation of industrial centers in urban settlements took place. Manufacturing locations and the formation of settlement system are closely interrelated and in fact constitute a single process. As a rule, a close correlation between the degree of industrial development of the area and the number of urban population is found, and that should be considered natural. As a result, this 
period is characterized by the direction of migration flows of rural population to large cities, as well as a push-pull migration from small and medium-sized towns located in the footprint of a large city. Thus, the urban growth occurred mainly due to the exhaustion of the demographic potential in rural areas.

A growing share of the major cities in the total urban population increases the polarization of geodemographic space. However, the impact of the settlement on the surrounding rural area increases in direct proportion to the size of the settlement. In this research, this effect can be traced through the increase of the indexes of density of rural population and the share of people of working age close to big cities (Minsk, Gomel, Mogilev, Vitebsk, Brest, Bobruisk, Baranovichi, Borisov, Orsha, Mozyr).

Growth in the share of urban population in Belarus is accompanied by expressive manifestation of the redistribution trend of urban population in favor of large cities. In 1970 , the proportion of rural population in the total population number was $56.7 \%$ and there were only 9 large and major cities in Belarus; their share of the total urban population was 56.4\%. By 1989 the number of large and major cities has increased slightly (up to 12), and the total number of their population almost doubled from 2,213,000 to $4,196,000$ people; and the share of the total urban population amounted to $62.8 \%$ (Pirozhnik, 2000). Currently, the share of urban population is $76.3 \%$, the number of cities with more than 100 thousand people is 14 , with the total number of 4,597,100 people or $65 \%$ of the total urban population of Belarus.

The system of urban population in western and south-western parts of Belarus is characterized by a greater role of medium, semi middle and large urban settlements than in other regions, and greater stability of these classes of cities (Antipova, Fakeyeva, 2012).

There are 3 large cities in Brest region (Brest, Baranovichi, Pinsk), 1 medium city (Kobrin) and 3 semi medium ones (Bereza, Ivatsevichi, Luninets). 66\% of the urban population fall to the share of large cities; $14 \%$ fall to medium and semi medium ones. The average population size of urban settlements is 31.7 thousand people (Antipova, Fakeyeva, 2012).

Grodno region is characterized by playing almost an equal role in the urban structure of large and medium cities. So, $45 \%$ of urban population falls to the share of the only major city in the region (Grodno), and 34\% falls to the share of medium and semi medium cities (Lida, Slonim, Volkovysk, Smorgon, Novogrudok) (Antipova, Fakeyeva, 2012).

The concentration of population in major cities in the context of the issue promotes the increase of the potential demand for agroecotourism services and supports generating factor in its development. However, the growth in demand will occur with the change of generations, after the retirement of the first and second-generation rural migrants living in cities, because they still tend to keep close ties with the countryside. Considering that the urbanization transition took place in 1975 and the considered period of generation is slightly more than 25 years, we can assume that the peak of the demand for authentic agroecofarmsteads is ahead.

If we talk about implementing factors we also have to at least mention the regional characteristics of rural settlements in Belarus. 
Regional features of rural settlements in Belarus are determined by the change in the number of people and the density of rural settlements in the direction from north to south (Spizhankov, 1985).

The dependence of the dynamics of demographic characteristics on the features of the settlement system has been studied in the geography of the population of Belarus since 1970s to the present (Spizhankov, 1974; Gurin, 1984; Spizhankov, 1985; Manak, 1992; Manak, Antipova, 2002; Antipova, 2008; Antipova, Fakeyeva, 2012). Our calculations do not contradict previous research studies and confirm the direct dependence of the stability degree of the demographic development and the population size in rural settlements.

Direct linear dependence of the birth rate and population size in rural settlements increased from 0.56 in 1970 to 0.95 in 2013, reflecting a more stable demographic development of densely populated type of settlement compared with an under populated one.

At the micro geographic level, the spatial distribution of the power of influence of the settlement system factor in 1970, has a uniform distribution, by 1989 it is characterized by progressive increase in the direction from the northwest to the south with the formation of the Central close-to-the-capital area. In the early 2000s this trend is maintained, indicating, firstly, the expansion of the boundaries of the under populated type southward and reduction of the number of densely populated areas, and secondly, the increase of population size of rural settlements in the area of influence of large cities.

The rural area of Brest region differs with bigger rural settlements, which largely helped to preserve the demographic stability of the region, the rural style of life and a high level of labor resource availability in the countryside. How these characteristics may contribute to the development of rural tourism has been considered above.

Grodno region, on the contrary, is presented by under populated and moderately populated types of rural settlements, is not characterised by demographic stability, has the highest rates of population aging, etc. However, these characteristics do not give grounds to assert that geodemographic development potential of agroecotourism in Grodno region is low. In Grodno region the settlement factor may act contributing to the development of agroecotourism in the first place through the remains of a farmstead settlement system. And as it is known a farm yard settlement system is preserved the most in the western part of Belarus.

Farm yards appeared in the 19th century and early 20th century, after the abolition of serfdom in connection with the development of the market economy. They acquired the greatest development during the Stolypin reforms (1906-1917), in western Belarus - during the Polish government pursued the policy of parceling (1921-1939) when Polish authorities settled about $70 \%$ of rural households to farm yards, which provided over 250 thousand farm yards. The farm yard settlement system was abolished in the eastern part of the country in the late 1920s - early 1930s, in the western part - by the end of 1960 (previously - 150 thousand). But some farm yards survived until the dissolution of the USSR. Besides, until 1989 about 1,000 settlements with the population of up to 5 people in each, actually, farm yards officially referred to villages and towns. 


\begin{tabular}{|c|c|c|c|c|c|c|c|}
\hline \multirow{6}{*}{ 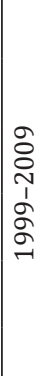 } & 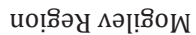 & $\varangle$ & $z$ & $z$ & $\varangle$ & $z$ & \multirow{4}{*}{$\begin{array}{l}0 \\
0 \\
0 \\
0 \\
0 \\
0 \\
0\end{array}$} \\
\hline & 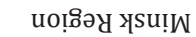 & $\varangle$ & $z$ & $z$ & $a$ & $a$ & \\
\hline & 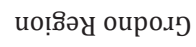 & $\varangle$ & z & $z$ & $\varangle$ & $z$ & \\
\hline & 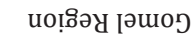 & $\varangle$ & 乙 & $z$ & 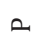 & $z$ & \\
\hline & 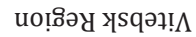 & $\varangle$ & $z$ & $z$ & $\varangle$ & $z$ & 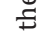 \\
\hline & 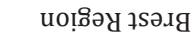 & $\varangle$ & $z$ & $z$ & $a$ & $z$ & שี \\
\hline \multirow{6}{*}{ 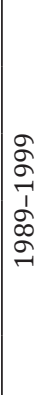 } & uo!̣ภว & $\varangle$ & $\varangle$ & $\varangle$ & $\varangle$ & $\varangle$ & $\underset{\Xi}{\mathscr{D}}$ \\
\hline & 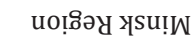 & $\varangle$ & $z$ & $\varangle$ & ص & $\varangle$ & 站 \\
\hline & 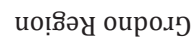 & $\varangle$ & $z$ & $z$ & $\varangle$ & $\varangle$ & 1 \\
\hline & uoเ̣ిวy [əயนо & $\varangle$ & $\varangle$ & $\varangle$ & ص & $\varangle$ & 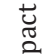 \\
\hline & 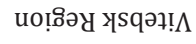 & $\varangle$ & z & $\varangle$ & $\varangle$ & $\varangle$ & $\stackrel{\Xi}{\Xi}$ \\
\hline & 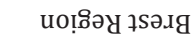 & $\varangle$ & $z$ & $z$ & ص & $\varangle$ & 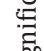 \\
\hline \multirow{6}{*}{ 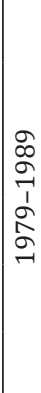 } & 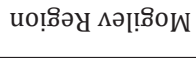 & $\varangle$ & $\varangle$ & $\varangle$ & $\varangle$ & $\varangle$ & $\begin{array}{l}n \\
0 \\
\Xi\end{array}$ \\
\hline & uo!̣อిวy ysu!̣ & $\varangle$ & z & $\varangle$ & $z$ & $\varangle$ & 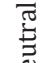 \\
\hline & 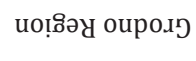 & $\varangle$ & $z$ & $\varangle$ & $\varangle$ & $\varangle$ & $\begin{array}{l}0 \\
1 \\
7\end{array}$ \\
\hline & 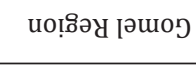 & $\varangle$ & $\varangle$ & $\varangle$ & $z$ & $\varangle$ & $\ddot{\vec{\Xi}}$ \\
\hline & 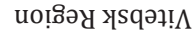 & $\varangle$ & $z$ & $\varangle$ & $\varangle$ & $\varangle$ & $\frac{\pi}{3}$ \\
\hline & บo!̣ిว 7 sว.ાg & $\varangle$ & $z$ & $\varangle$ & $a$ & $\varangle$ & $\frac{\pi}{0}$ \\
\hline \multirow{6}{*}{ 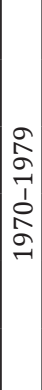 } & uо!̣ภว & $\varangle$ & $z$ & $\varangle$ & $\varangle$ & $z$ & I \\
\hline & 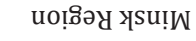 & $\varangle$ & $z$ & $\varangle$ & $z$ & $\varangle$ & ]ี \\
\hline & иоเ̣ిวy оupoxท & $\varangle$ & $z$ & $a$ & $\varangle$ & z & $\underbrace{0}_{0}$ \\
\hline & 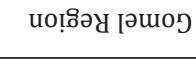 & $\varangle$ & $z$ & $z$ & a & z & $\begin{array}{l}\tilde{\sigma} \\
1\end{array}$ \\
\hline & 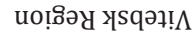 & $\varangle$ & $z$ & $\varangle$ & $\varangle$ & $z$ & $\ddot{\Xi}$ \\
\hline & 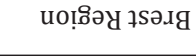 & $\varangle$ & $z$ & $a$ & a & z & $\frac{0}{3}$ \\
\hline 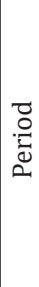 & 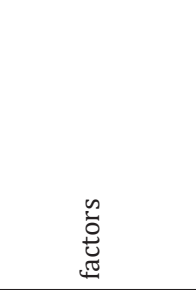 & 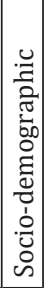 & 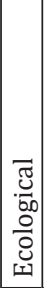 & 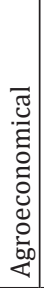 & 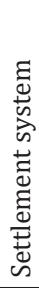 & 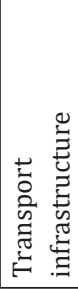 & $\begin{array}{l}0 \\
0 \\
0 \\
0 \\
0 \\
0 \\
\frac{0}{\omega} \\
4 \\
0 \\
0 \\
0 \\
0 \\
0\end{array}$ \\
\hline
\end{tabular}


The restoration of farm yards is observed in the areas where there are large farms, particularly in Grodno and Brest ones and in western districts of Minsk and Vitebsk regions. At the beginning of the 1990s there were 2181 farm yards (about $8 \%$ of all rural settlements) (Sharukho, 2007: 119-120).

Comparative geographical assessment of the major factors of demographic development in the regions of Belarus is shown in the summary analytic table (Tab. 2).

\section{CONCLUSION}

The results of the factor analysis indicate that during the period of 1970-1979 the factors determining the spatial heterogeneity of population dynamics in the rural areas of Belarus were agro-economic indicators (agriculture gross income, quality of agricultural lands, power availability of agriculture), settlement characteristics (population size of rural settlements, the degree of urbanization), transport and communication characteristics (density of paved roads) dominated from 1989 to present days. Thus, during the analyzed period there is a tendency to reduce the impact of the development level of agricultural production on the demographic dynamics and to strengthen the role of transport infrastructure and geographical proximity to the city.

Geodemographical factors of agroecotourism development are potentially contributing in the studied areas, Brest and Grodno regions. Basic competitive advantages for Brest region are demographic stability of the southern agricultural areas with high demographic and labor resource potential, the preserved rural way of life.

\section{References}

Antipova, E.A. (2008). Geodemograficheskie problemyi i territorialnaya struktura selskogo rasseleniya Belarusi. Minsk: Belorusskiy gosudarstvenniy universitet (in Russian).

Antipova, E., Fakeyeva, L. (2012). Settlement System of Belarus. Spatial and Temporal Trends at the end of $20^{\text {th }}$ and the beginning of the $21^{\text {st }}$ Centuries. Journal of Settlements and Spatial Planning, 3(2), 129-139.

Fakeyeva, L. (2009). Economic-geographical factors and regional tendencies of rural Belarus depopulation: avtoreferat dissertatsii kandidata geograficheskih nauk. Minsk: Belorusskiy gosudarstvenniy universitet (in Russian).

Gaidukevich, L.M., Tarasenok, A.I., Reshetnikov, D.G., Poleschuk, N.I. (2001). Turizm v Belarusi. Minsk: Belorusskiy gosudarstvenniy universitet (in Russian).

Gartsueva, E.Ya. (2007). Planirovanie razvitiya selskikh rajonov. In: Byl V.I. (ed.). Territorialnoye planirovaniye $v$ Respublike Belarus. Minsk: FUAinform, 222-229 (in Russian).

Gurin, N.N. (1984). Problemyi pereustroystva selskogo rasseleniya v zonah vliyaniya krupnyih gorodov (na primere g. Minska): avtoreferat dissertatsii kandidata geograficheskih nauk. Minsk: Belorusskiy gosudarstvenniy universitet (in Russian).

Kliunya, V.L. (2000). Economicheskie problemy razvitiya argopromyshlennogo ckompleksa $v$ usloviyakh perekhodnoy economiki: avtoreferat dissertatsii doktora ekonomiczeskich nauk. Minsk: Belorusskiy gosudarstvenniy universitet (in Russian).

Leschilovskiy, P.V. (1998) Formirovanie i ispolzovanie trudovykh resursov selskogo khozyajstva $v$ usloviyakh perekhoda $k$ rynku: (teoriya, metodologiya, practika): avtoreferat dissertatsii doktora ekonomiczeskich nauk. Minsk: Bel NII ekonomiki i informatsii agropromyshlennogo compleksa (in Russian). 
Manak, B.A. (1992). Naselnitstva Belarusi: regiyanalnyiya asablivastsi razvitstsya i rassyalennya. Minsk: Universitetskae (in Belarussian).

Manak, B.A., Antipova, E.A. (2002). Demograficheskie poteri i sovremennyie trudoresursnyie vozmozhnosti selskoy mestnosti Belarusi. Minsk: UP "Tehnoprint” (in Russian).

National Statistical Committee of the Republic of Belarus (2016, 24 January). www.belstat.gov.by Pirozhnik, I.I. (1986). Ekonomiko-geographicheskaya tipologiya rajonov Belorusskoy SSR. Vestnik BGU. Seriya 2. Khimiya. Biologiya. Geographiya, 3, 63-67. (in Russian).

Pirozhnik, I.I. (2000). Prostranstvennye askekty urbanizatsii Belarusi. Vestnik BGU. Seriya 2. Khimiya. Biologiya. Geographiya, 3, 77-82 (in Russian).

Sharukho, I.N. (2007). Istoricheskie tipy selskogo rasseleniya Belarusi: kulturno-geographicheskije osobennosti. Pskovskiy regionologicheskiy zhurnal, 5, 115-133 (in Russian).

Spizhankov, L.I. (1974). Selskoe rasselenie Belorussii. Minsk: Vyisheyshaya shkola (in Russian).

Spizhankov, L.I. (1985). Preobrazovaniye belorusskogo sela. Minsk: Uradzhaj (in Russian).

Tupitscyna, N.B. et al. (ed.) (2015). Agroecotourism development in frontier regions at the example of Brest and Grodno regions. Minsk: Smeltok.

Liudmila Fakeyeva, Ph.D. in Geography, Associate Professor, Belarusian State University, Faculty of International Relations, Department of International Tourism. In 2007-2016 worked as a teaching assistant, lecturer and associate professor of the Faculty of Geography, Economic Geography of Foreign Countries Department, Belarusian State University. Since 2016 - associate professor of the Faculty of International Relations, Department of International Tourism, Belarusian State University. Scientific and Research Interests: population geography, regional socio-economic development, recreational geography and tourism.

\section{Address:}

Belarusian State University

Faculty of International Relations

Department of International Tourism

Bulding 4, Nezavisimosti avenue, 220030 Minsk, Belarus

e-mail: fokeeva@tut.by

Aliaksei Shadrakou, Ph.D. in Geography, docent, Scientific Department of the Economy Research Institute of the Ministry of Economy of the Republic of Belarus, senior research associate. In 2005-2007 worked as a teaching assistant of the Department of Geography and Nature protection in Mogilev State University. In 2010 - the senior lecturer and in 2012 - the head of the Department of Geography and Nature protection in the university. Since 2014 - the seniour research associate at Scientific Department of the Economy Research Institute of the Ministry of Economy of the Republic of Belarus. Scientific and research interests are state regional socio-economical politics, transboundary collaboration, space planning and teaching process.

\section{Address:}

Ministry of Economy of the Republic of Belarus

Economy Research Institute

Scientific Department

Building 1, Slavinskogo Street, 220086 Minsk, Belarus

e-mail: alshadrakov@yandex.ru 